\title{
Penerapan Norma Adat Terang dan Tunai dalam Praktek Pe- radilan Perdata (Kajian Putusan Pengadilan nomor: 23/pdt.g/2013/pn.bj)
}

\author{
Laila M Rasyid \\ ${ }^{1}$ Dosen Fakultas Hukum Universitas Malikussaleh \\ laila.mrasyid@unimal.ac.id
}

\begin{abstract}
Tulisan ini merupakan analisis atas pertimbangan hukum yang dilakukan oleh hakim dalam kasus Wanprestasi yang mengandung unsur hukum adat yaitu azas terang dan tunai. Penelitian ini adalah penelitian yuridis-normatif dengan pendekatan kualitatif. rumusan masalah dalam penelitian ini adalah bagaimana penerapan konsep adat terang dan tunai dalam praktek peradilan perdata berdasarkan Putusan Nomor :23/Pdt.G/2013/Pn.Bj. Hasil penelitian menunjukkan bahwa Hukum Positif dan hukum adat dapat digunakan bersama dalam hukum Indonesia karena memiliki tujuan yang sama yaitu untuk tercapainya keadilan. Dalam tulisan ini terdapat dissending opinion diantara majelis hakim yang memutuskan apakah ada unsur adat atau positif di dalam fakta hukum. hukum positif mungkin saja tidak sempurna dan terbatas dalam mengartikan sesuatu dan hukum adat boleh saja digunakan dalam tujuan untuk tercapainya keadilan, kepastian dan kemanfaatan hukum untuk masyarakat.
\end{abstract}

Keyword: Hukum Adat, Hukum Positif, Wanprestasi. 


\section{PENDAHULUAN}

Tulisan ini dilatarbelakangi oleh anggapan bahwa hakim dalam membuat pertimbangan hukum tidaklah sekedar hanya menjalankan perintah hukum formal secara yuridis dan procedural saja. Namun yang terpenting dalam setiap putusan hakim adalah lahirnya suatu putusan yang dapat menyampaikan tujuan hukum yang sesungguhnya yaitu berkeadilan, bermanfaat, dan berkepastian hukum (Suwito, 2015). Putusan hakim hendaknya juga berfungsi untuk menjaga ketertiban sosial. Keadilan, kepastian hukum, kemanfaatan sebagaimana dikatakan oleh Gustav Raadbruch adalah tiga terminologi yang ternyata setelah dicermati bermuara pada kepastian hukum demi tegaknya the rule of law. Jadi, pada dasarnya keadilan dan kepastian hukum tidak berseberangan melainkan justru bersandingan (Suwito, 2015).

Pengertian hukum dapat juga diartikan sebagai hukum yang tersaji (given), yakni norma-norma positif dalam sistem perundangundangan. Hakim memang dianjurkan untuk menggali nilai-nilai yang hidup di dalam masyarakat, tetapi pada kenyatannya para hakim selalu diajarkan untuk memfokuskan pertimbangannya pada pasal-pasal undang-undang yang ada dalam gugatan. Putusan hakim yang baik adalah seperti mahkota dimana putusan yang dibuat setelah melalui semua pemeriksaan. Kewibawaan hakim hanya mungkin dipahami oleh masyarakat apabila hakim dapat menuangkannya ke dalam putusannya secara baik melalui pertimbangan hukum. Neil Mac Cormick berpesan kepada para hakim dengan menyatakan;

"since they are required to state the reasons for their decisions, they must not merely reason out, they must publicly state and expound, the justifying reasons for their decisions- hence their eminent accessibility to study"

Putusan hakim dituntut untuk memuat pertimbanganpertimbangan (motivering vonis) yang mampu menjawab kebutuhan zamannya. Oleh karena itu setiap putusan hakim harus dianggap benar (res judicata pro veritate habetur) sampai ada putusan lain diatasnya yang menyatakan kebatalan putusan tersebut, maka wajar jika putusan hakim akan selalu dievaluasi publik, khususnya oleh pengamat hukum. Disamping itu, hakim adalah makhluk intelektual dan etis yang layak diberi keleluasaan untuk berkarya, dan karena karya tersebut dialamatkan kepada publik, maka layak pula bagi public untuk meminta pertanggungjawabannya, termasuk pertanggungjawabannya atas tujuan- 
tujuan hukum yang secara fundamental dan proporsional melekat pada setiap putusan; keadilan, kepastian hukum dan kemanfaatan. (Suwito, 2015)

Berkaitan dengan jabatannya, hakim harus mengadili setiap perkara yang diajukan ke pengadilan dan tidak boleh menolaknya dengan alasan belum ada hukum tentang perkara tersebut. Inilah yang dimaksud dengan asas ius curia novit. Di dalam melaksanakan kewenangan untuk mengadili perkara tersebut, hakim mendasarkan diri pada hukum, baik tertulis dan atau hukum tidak tertulis (hukum adat) sebagai dasar pertimbangan setiap putusan (Sulastriyono, 2012). Jika hakim menggunakan hukum adat dalam menyelesaikan suatu perkara maka putusannya dapat berupa (a) putusan menyamakan; (b) putusan menyesuaikan; (c) putusan mengesampingkan; (d) putusan jalan tengah; (e) putusan mengubah; (f) putusan baru; dan (g) putusan menolak. (Hilman Hadikusuma, 1992)

Hukum adat sebagai hukum yang hidup dan eksis di masyarakat (living law), adalah sebuah kenyataan yang tidak dapat diabaikan. Hukum adat merupakan nilai sosial dan keadilan masyarakat, ia menjadi bagian yang tidak terpisahkan dalam kehidupan masyarakat. Oleh karena itu meskipun masih ada hukum barat, baik itu yang diatur dalam KUHP, KUHPer, BW dan peraturan lainnya yang berlaku di Indonesia, akan tetapi nilai dan kearifan local dari masyarakat adat senantiasa tetap ada sebagai realitas yang dari waktu kewaktu tidak dapat dihindarkan.

Von Savigny menyatakan bahwa "hukum adalah pernyataan dari jiwa bangsa", dengan ungkapannya yang terkenal bahwa "das recht wiid nicht gemacht, es its und wird mit den volke", yang artinya "hukum itu tidak dibuat melainkan berada dan berkembang dengan bangsa itu sendiri"(Juju Ahmad Jayus, 2019). Hukum adat juga merupakan realitas yang hidup, menyatu dan berada ditengah masyarakat, disusun berdasar sistem nilai dan budaya masyarakat. Sebagai tingkatan sosial, hukum adat berfungsi sebagai alat yang digunakan untuk menjaga keseimbangan "stabilisator" masyarakat, dari segala kegoncangan akibat pelanggaran peraturan-peraturan hukum maupun pelanggaran terhadap norma-norma kesusilaan, keagamaan dan sopan santun dalam masyarakat.

Hukum modern dan hukum adat dapat berjalan bersama dalam sistem hukum Indonesia yang syarat dengan pluralisme dimana ada lebih dari satu sistem hukum yang dipakai. Pada beberapa daerah di Indonesia hukum adat juga sudah mendapat pengakuan sebagai ba- 
gian dari hukum positif. Namun, dalam beberapa kasus harus berhadapan antara hukum positif dengan hukum adat seperti putusan mengenai wanprestasi di Pengadilan Negeri Binjai. Kedua hukum tersebut memiliki tujuan yang sama yaitu keadilan yang tidak bisa sepenuhnya dipastikan dalam rumusan hukum.(Putro, 2009)

Berangkat dari latar belakang pandangan ahli hukum diatas, pada tulisan ini akan diambil satu putusan untuk dapat dijadikan contoh bagaimana hakim melakukan penanganan suatu kasus hukum. Putusan yang dipilih berasal dari Majelis Hakim Pengadilan Negeri Binjai yang dibacakan pada hari Rabu Tanggal 18 Juni 2014, dengan registrasi perkara Nomor 23/Pdt.G/2013/PN.BJ. Putusan ini terdiri dari 47 halaman kertas ukuran kuarto dengan jarak ketikan 1,5 spasi. Dari total jumlah halaman tersebut, pertimbangan hakim terkait "tentang hukumnya" dan "dalam pokok perkara" terdiri dari 15 halaman, dengan adanya Dissending Opinion dari anggota majelis hakim II mengenai asas terang dan tunai dalam konsep hukum adat.

\section{METODE PENELITIAN}

Berdasarkan latar belakang di atas, rumusan masalah yang hendak dianalisis dalam tulisan ini adalah bagaimanakah penerapan konsep adat terang dan tunai dalam praktek peradilan perdata berdasarkan Putusan Nomor :23/Pdt.G/2013/Pn.Bj?

Pada dasarnya, tujuan penulisan ini adalah untuk mengetahui dan menganalisisi konsep terang dan tunai dalam masyarakat adat; mengetahui penerapan konsep tersebut dalam putusan peradilan perdata; dan mendapatkan gambaran yang utuh terkait pertimbangan hakim dalam penerapan konsep tersebut. Kegunaan dari penulisan ini adalah sebagai tambahan dalam ilmu pengetahuan terutama perdata yang akan mendorong perkembangan nilainilai dan konsep adaat di Indonesia yang dapat dipergunakan oleh hakim dalam menyelesaikan sebuah persoalan nantinya.

Penelitian ini merupakan penelitian yang bersifat yuridis normatif yaitu penelitian hukum yang bertujuan mencari kaidah, norma atau das sollen. Penelitian ini disebut penelitian hukum normatif yang bersifat deksriptif karena dimaksudkan untuk memberikan gambaran yang rinci tentang focus yang diteliti dengan memanfaatkan norma-norma hukum yang ada, sehingga dapat menjawab permasalahan yang diteliti.Sarana yang digunakan adalah studi dokumen, metode analisis yang digunakan dalam tulisan ini adalah 
analisis kualitatif. (Soerjono Soekanto, 1984)

\section{HASIL DAN PEMBAHASAN}

\subsection{Pengertian Konsep terang dan} Tunai dalam hukum adat Indonesia

Hukum adat di Indonesia memiliki sifat dan corak khas yang berbeda dari hukum-hukum lainnya. Hukum adat bersifat pragmatism-realisme yang artinya hukum adat mampu memenuhi kebutuhan masyarakat yang bersifat fungsional religious. Ada empat sifat umum dari masyarakat adat yang antaranya adalah terang dan tunai (kontan).

Sifat terang (concrete) diartikan sebagai corak masyarakat hukum adat yang serba jelas atau nyata, menunjukkan bahwa setiap hubungan hukum yang terjadi dalam masyarakat tidak dilakukan secara diam-diam atau samar, dengan kata lain terbuka (Suriyaman Mustari Pide, 2014). Misalnya transaksi jual-beli yakni setiap kesepakatan selalu diiringi dengan adanya pemindahan benda, baik bergerak maupun tidak. Pendapat lain tentang sifat konkrit ini yaitu dalam hal tertentu sienantiasa dicoba supaya hal-hal yang dimaksudkan, diinginkan, dikehendaki, atau akan dikerjakan, ditransformasikan atau diberi ujud sebuah benda, diberi tanda yang kelihatan baik langsung maupun hanya menyerupai objek yang dikehendaki. (Tolib Setiady, 2008)

Sifat kontan (tunai) ini mengandung arti keserta-mertaan, utamanya dalam hal pemenuhan prestasi. Sifat kontan memberi pengertian bahwa suatu tindakan berupa perbuatan nyata, perbuatan simbolis atau pengucapan akan serta merta menyelesaikan tindakan hukum serentak dengan waktunya manakala ia melakukan perbuatan menurut hukum adat (Suriyaman Mustari Pide, 2014). Pendapat lain mengartikan sifat ini suatu pernyataan nyata atau suatu perbuatan simbolis tindakan hukum yang dimaksud telah selesai seketika itu juga dengan serentak bersamaan waktunya tatkala berbuat atau mengucapkan yang diharuskan oleh adat. (Tolib Setiady, 2008)

Sebagian orang berpendapat Jual beli yang dibuat secara lisan dimana subjek dan objek perjanjian hanya dapat diyakini oleh para pihak yang membuat perjanjian perikatan, dan tidak diatur secara spesifik dalam KUHPerdata sebaiknya tidak dipergunakan karena dalam hal pembuktiannya sulit karena beban pembuktian dalam hukum perdata dibebankan pada kebenaran formil, serta menimbulkan tidak adanya kepastian hukum dan menjadi sulit ketika 
timbul sengketa atau ketidaksesuai pendapat.(Amir Mahmud Brutu, 2019)

Meskipun menurut teori, suatu perjanjian, atas dasar kata sepakat, terjadinya oleh karena adanya niat dari orang=orang yang bersangkutan akan tetapi secara praktis yang merupakan pegangan adalah pernyataan niat tersebut, dari pernyataan niat yang timbal balik tersebut, maka terjadilah suatu perjanjian dan dari perjanjian itu keluarlah hak dan kewajiban kedua belah pihak atau salah satu pihak diantaranya.

Jual beli tanah secara lisan atau berdasarkan hukum adat dalam praktek sehari-hari masih banyak dilakukan oleh sebagian masyarakat di Indonesia. Khususnya masyarakat yang keadaan ekonominya lemah dan tingkat pendidikannya masih rendah. Hal ini disebabkan masih adanya pengaruh hukum adat yang menentukan bahwa jual beli ha katas tanah adalah sah apabila telah terpenuhi syarat "terang dan tunai".(Amir Mahmud Brutu, 2019)

Hukum adat tidak membedakan antara hak kebendaan (zakelijke rechten) yaitu hak-hak atas bedan yang berlaku bagi setiap orang, dan hak perseorangan (persoonlijke rechten) yaitu hak seorang untuk menuntut orang lain agar berbuat atau tidak bebrbuat terhadap hak-haknya. Menurut hukum barat setiap orang yang mempunyai ha katas sesuatu benda, berarti ia berkuasa untuk berbuat (menikmati, memakai, mentransaksikan) benda milikya itu dan sekaligus karenya mempunyai hak perorangan atas hak miliknya itu. Antara kedua hak itu tidak terpisah.(Hilman Hadikusuma, 1992)

\subsection{Analisis Putusan Pengadilan Nomor 23/Pdt.G/2013/PN.BJ.}

Setiap putusan hakim memiliki kekuatan hukum yang harus ditaati oleh semua pihak karena selain putusan itu memenuhi aspek formal yang disebut procedural Justice, juga didasarkan kepada prinsip utamanya yaitu aturanaturan atau norma-norma yang ada dan benar-benar mengikuti prinsip hukum yang dikenal sebagai Legal Justice (putusan hakim harus merupakan putusan yang memenuhi ketentuan formalitas dan mempunyai persyaratan legitimasi)(Gayus Lumbuun, 2004).

Pedoman bagi seorang hakim dalam mengambil sebuah keputusan pada sebuah perkara pidana maupun perdata tentunya berdasarkan pada legal justice dengan menempatkan hukum sebagai hukum (law is law). Prinsip filosofis ini sesuai dengan ketentuan Undang-Undang Nomor 14 Tahun 1970 Tentang Ketentuanketentuan Pokok Kehakiman Pasal 4 ayat I sebagaimana diubah den- 
gan Undang-Undang Nomor 48 Tahun 2009 yang menggariskan "Pengadilan mengadili menurut hukum dengan tidak membedabedakan orang".

Putusan hakim adalah hukum yang sebenar-benarnya the real law). Asumsi dasar itu dikemukakan oleh aliran realism hukum yang menyatakan bahwa all the law is judge made law. Artinya semua hukum itu pada hakikatnya adalah putusan hakim, sehingga posisi dan kedudukan hakim menjadi pusat lahirnya hukum. Oleh karena itu putusan hakim sebagai hukum yang sejatinya, harus dapat mewujudkan tujuan hukum itu sendiri.(Syamsudin, 2014)

Pada akhir-akhir ini masyarakat dibingungkan dengan adanya putusan hakim yang saling berbeda dengan putusan hakim di tingkat pertama dengan putusan hakim di tingkat banding dan kasasi untuk sebuah perkara yang sama dan yang sama-sama didasarkan kepada legal justice dengan procedural justice yang mempunyai aspek legitimasi.

Melihat kepada keputusankeputusan yang sangat berbeda padahal didasarkan pada pertimbangan hukum atas peristiwa yang sama melalui procedural justice yang sama pula, menimbulkan penilaian bahwa aspek moralitas yang menggambarkan nilai-nilai keadilan dengan didasarkan pada kebijaksanaan dan kearifan hakim dalam mengambil keputusan sebagai aparat negara dalam melaksanakan tugasnya masih tidak sama.

Putusan hakim adalah putusan yang terkait kasus-kasus konkret, maka dengan sendirinya putusan hakim adalah putusan yang berangkat dari problem (problem based thinking). Namun pada saat hampir bersamaan, hakim juga akan mengaitkan problem ini dengan pengetahuannya tentang keseluruhan sistem hukum yang berlaku.keterkaitan kedua hal ini untuk memastikan bahwa pertimbangan hakim merupakan perkara hukum bukan sekedar peristiwa konkrit biasa.(Shidarta, 2010)

Asas Ius Curia Novit dianggap hakim tahu hukum sehingga hakim dapat menggunakan pengetahuannya untuk keluar dari dasar hukum yang disampaikan kepadanya, sekalipun misalnya ia tahu ada dasar hukum lain yang sebenarnya lebih layak digunakan untuk meneyelesaikan kasus tersebut.

Selama ini, para hakim di Indonesia menggunakan norma dan asas-asas hukum adat sebagai bahan pertimbangan dalam menjatuhkan putusannya jika perundang-undangan sebagai sumber hukum yang utama belum mengatur atau tidak secara jelas mengatur tentang suatu peristiwa hukum 
tertentu. Yurisprudensi Makhkamah Agung yang terkait dengan persoalan-persoalan hukum adat masih tersebar dan mencakup berbagai aspek dalam kehidupan bermasyarakat. Dalam sistem hukum yang berlaku di Indonesia, putusan hakim terdahulu tidak mengikat bagi hakim lain yang akan memutuskan perkara sejenis.(Sulastriyono, 2012)

Dalam hukum adat terdapat beberapa ciri-ciri yang membedakannya dengan hukum barat antara lain :

1. Religio Magis : Bahwa pada hukum adat terdapat unsur percaya kepada kekuatan ghaib dan tidak berdasarkan pada logika dan kenyataan semata. Misalnya: Upacaraupacara adat lazimnya diadakan sesajen-sesajen yang ditujukan kepada roh-roh leluhur yang ingin diminta restu serta bantuannya.

2. Komunal (kebersamaan). Menunjukkan bahwa hukum adat pada dasarnya mengatur kepentingan bersama dan kaedah-kaedahnya kebanyakan berlaku umum, tidak mengatur secara rinci individual seperti dalam hukum barat.Misalnya: perjanjian yang berhubungan dengan tanah pertanian tidak perlu dibuat kasus perkara karena telah ada ketentuan yang ba- ku tentang hak dan kewajiban masing-masing pihak dalam hukum adat yang berlaku umum.Kemudian sifat kebersamaan juga terlihat dalam kebiasaan dalam masyarakat yang saling tolongmenolong dan bantumembantu.

3. Kontan yaitu menunjukkan bahwa transaksi dalam hukum adat dikehendaki terjadi secara kontan, sehingga prestasi dan kontra prestasi terlaksana serentak.Misalnya: Jual, apabila benar-benar terlihat adanya tindakan pembayaran kontan dari si pembeli serta penyerahan barang dari si penjual.

4. Kongkrit yaitu menunjukkan bahwa sahnya suatu hubungan hukum menurut hukum adat, apabila perbuatan hukum itu terjadi secara nyata, adanya pemberian tandatanda yang kelihatan untuk bukti penegasan atau peneguhan daripada apa yang telah dilakukan atau yang dalam waktu dekat akan dilakukan.Misalnya: pemberian panjar pada transaksi jualbeli.

Kasus dalam putusan ini berawal dari gugatan perdata seseorang bernama Nuraini melawan tergugat Hendri Z selaku tergugat 1, Arbiah Selvi tergugat II, dan Wi- 
dianti tergugat III, Penggugat Nuraini pada Tahun 2005 mempersoalkan bahwa penggugat adalah pemilik sah dari sebidang tanah dengan luas 147 meter persegi yang diatasnya berdiri bangunan semi permanen untuk rumah tempat tinggal yang dimiliki oleh penggugat berdasarkan akta jual beli dengan para tergugat.

Terhadap kesepakatan jual beli tersebut terbitlah sertifikat hak milik atas nama penggugat beserta tanah dan bangunan dan pata tergugat harus menyerahkan tanah tersebut, akan tetapi para tergugat tidak menyerahkan dan mengosongkan tanah yang menjadi objek perkara, sehingga terjadilah wanprestasi atau ingkar janji atas kesepakatan jual beli tersebut. Akibat perbuatan tergugat, penggugat menyatakan telah menderita kerugian Rp. 200.000.000.

Atas dasar itu, penggugat minta kepada majelis hakim agar dalam provisi diletakkan sita jaminan terhadap objek sengketa. Sementara dalam pokok perkara primer meminta majelis (1) mengabulkan gugatan penggugat untuk seluruhnya; (2) menyatakan penggugat adalah pemilik sah atas objek sengketa; (3) menyatakan tergugat I, tergugat II dan tergugat III telah melakukan perbuatan ingkar janji (wanprestasi), karena tidak menyerahkan objek perkara kepada penggugat;(4) menyatakan sah dan berharga sita jaminan (conservatoir beslag) yang diletakkan dalam perkara ini; (5) menghukum tergugat I, tergugat II dan tergugat III untuk membayar ganti kerugian karena penggugat tidak dapat menguasai tanah dan bangunan tersebut, sebesar Rp. 200.000.000,-; (6) menghukum para tergugat untuk membayar jasa pengacara secara tanggung renteng kepada penggugat $\mathrm{Rp}$. $50.000 .000,-$; (7) menghukum tergugat I, tergugat II dan tergugat III untuk membayar uang paksa (dwangsom) sebesar Rp. 250.000,perhari bila tergugat I, tergugat II dan Tergugat III lalai menjalankan putusan yang telah berkekuatan hukum dalam perkara ini; (8) menyatakan agar Pengadilan Negeri Binjai /Majelis hakim yang menyidangkan perkara ini mengembalikan rumah tersebut kepada pengguat seperti semula;(9) menyatakan dalam perkara ini dapat dijalankan serta merta kendatipun ada verzet, banding atau kasasi;(10) membebankan biaya perkara kepada para tergugat.

Dalam jawaban atas surat gugatan tersebut, tergugat mengajukan eksepsi. Dalam eksepsi tersebut tergugat mengajukan beberapa hal yang kemudian seluruhnya ditolak oleh majelis hakim yaitu yang menyangkut :

1. Gugatan error in Persona; 
2. Gugatan kurang pihak, menurut tergugat karena penggugat tidak menarik Siti Syarifah ,S.H selaku notaris;

3. Gugatan Obscuur libel;

4. Kuasa pengguat tidak memiliki Legal Standing mengajukan gugatan.

Dalam pokok perkaranya, Tergugat juga mengutarakan tidak pernah menjual tanah dan bangunan sebagaimana yang didalilkan oleh penggugat, bahwa yang benar adalah para tergugat adalah ahli waris yang sah dari tanah milik Alm Zainal tersebut dan belum pernah dibagi atas harta peninggalan tersebut. Bahwa tidak benar para tergugat melakukan tindak wanprestasi sebagaimana dalil penggugat maupun tindakan pidana sebagaimana tuduhan penggugat sewaktu membuat laporan kepada pihak kepolisian di Polsek Kota Binjai dan dalam fakta di persidangan ternyata tergugat I tidak terbuktimelakukan kecurangan atau penipuan dalam hal jual beli tanah dan bangunan.

Bahwa para tergugat tidak pernah menghadap notaris yang disebut dalam surat gugatan dan tidak pernah membubuhkan tanda tangan pada Akta Jual Beli serta tidak pernah menyepakati dan atau menerima uang sebagai harga tanah dan bangunan yang menjadi objek sengketa, sehingga jual beli ini tidak sah dan cacat hukum.
Atas fakta-fakta yang diyakini majelis hakim tersebut, akhirnya pengadilan memutuskan (dalam pokok perkara) untuk (1) mengabulkan gugatan penggugat untuk seluruhnya; (2) menyatakan bahwa objek perkara berupa tanah dan bangunan permanen diatasnya adalah milik penggugat;(3) menyatakan tergugat-tergugat telah melakukan perbuatan ingkar janji (wanprestasi); (4) menghukum tergugat- tergugat untuk menyerahkan objek perkara kepada penggugat dalam keadaan semula; (5)dan menghukum para tergugat untuk membayar biaya perkara.

Terhadap putusan hakim ini ada suatu pandangan yang menarik yaitu adanya Dissending Opinion diantara ketua majelis, hakim anggota I dan hakim anggota II, dimana hakim anggota II telah mengemukakan pendapatnya sendiri. Hakim anggota II tidak sependapat dengan mayoritas pendapat hakim lainnya tentang pemilikan tanah dan bangunan yang menjadi objek perkara dalam perkara ini, dengan alasan berdasarkan bukti di persidangan bahwa para tergugat adalah pemilik tanah yang menjadi objek sengketa yang diperoleh dari warisan orangtuanya, sesuai Pasal 20 ayat (1) UUPA dan ini sah serta sesuai dengan hukum.

Selanjutnya para tergugat telah melakukan pemindahan hak milik tersebut dengan cara jual beli 
yang dibenarkan dalam Pasal 26 ayat (1) UUPA dan diatur dengan peraturan pemerintah. Bahwa jual beli yang diakui dalam UUPA adalah jual beli menurut hukum adat yaitu suatu perbuatan pemindahan hak, yang sifatnya kontan, riil dan terang.

Sifat kontan berarti bahwa penyerahan hak dan pembayaran harganya dilakukan pada saat yang sama. Sifat Riil berarti bahwa dengan mengucapkan kata-kata dengan mulut saja belumlah terjadi jual-beli. Jual-beli dianggap terjadi dengan penulisan kontrak jual-beli di muka kepala kampung serta penerimaan harga oleh penjual, meskipun tanah yang bersangkutan masih berada dalam pengawasan penjual. Sifat terang dipenuhi pada umumnya pada saat dilakukannya jual-beli disaksikan oleh kepala kampung, karena kepala kampuing dianggap orang yang mengetahui hukum dan kehadirannya mewakili masyarakat desa tersebut.

Selanjutnya dalam masyarakat hukum adat jual beli tanah dilaksanakan secara terang dan tunai, terang berarti perbuatan hukum jual-beli benar-benar dilaksanakan dihadapan kepala adat atau kepala desa. Tunai berarti adanya dua perbuatan dilaksanakan secara bersamaan yaitu pemindahan hakatas tanah yang menjadi objek jual-beli dari pen- jual kepada pembeli dan pembayaran harga dari pembeli kepada penjual terjadi serentak dan secara bersamaan.

Terhadap sengketa ini pembayaran tidak dilakukan secara lunas dikarenakan penggugat memotong langsung harga pembayaran dari jumlah harga yang diperjanjikan menurut kesepakatan antara penggugat dan tergugat. Bahwa dalam proses jual-beli tanah harus dipisahkan dari pembayaran hutang-piutang karena itu bukanlah kesepakatan awal terjadinya perjanjian jual-beli tanah antara penggugat dan para tergugat. Sehingga menurut Hakim Anggota II penggugatlah yang ingkar janji dan tidak sepatutnya jika para tergugat harus dihukum untuk mengganti kerugian tersebut.

Berdasarkan pertimbangan hakim dalam putusan diatas, dapat dilihat dasar pertimbangan hakim dalam memutuskan perkara tersebut adalah hukum positif yaitu para tergugat melakukan wanprestasi karena tidak melaksanakan perjanjian sesuai dengan yang sudah disepakati yaitu jual-beli tanah berikut bangunan yang berada diatasnya dan Dissending Opinion dari Hakim Anggota II yang mendalilkan norma hukum adat bahwa ingkar janji terjadi karena sifat Terang dan Tunai dalam jual-beli tersebut tidak ada, dikarenakan penggugat tidak melaksanakan ke- 
sepakatan awal terjadinya perjanjian jual-beli sesuai dengan nilai uang yang sudah disepakti akan tetapi penggugat membayar hanya sejumlah uang sesudah dipotong hutang Tergugat III pada Penggugat.

Menurut pendapat Jhon Salindeho yang menyatakan jual-beli tanah menurut hukum adat adalah

1. Hukum adat tidak mengenal pembagian bahkan pengertian "obligatoir" dan atau zakelijk (kebendaan) seperti hukum barat.

2. Suatu jual-beli pada hakikatnya bukan persetujuan belakang yang berada antara dua pihak (penjual dan pembeli), tetapi suatu penyerahan barang oleh penjual kepada pembeli dengan tujuan/maksud memindahkan hak di antara kedua belah pihak.

3. Kalau tidak dibayar kontan berarti bukan jual-beli, tetapi hutang piutang.

4. Para ahli hukum adat menegaskan bahwa sifat jual-beli lebih bersifat mengalami sendiri secara nyata, terang dan tunai (contant, concrete, belevend en participarent denken).

Dasar normatif penerapan norma adat dalam peradilan perdata adalah Pasal 5 ayat (1) dan (2) UU No 48 Tahun 2009 tentang
Kekuasaan Kehakiman, bahwa “ hakim dan hakim konstitusi wajib menggali, mengikuti dan memahami nilai-nilai hukum dan rasa keadilan yang hidup dalam masyarakat". Ketentuan ini merupakan kewajiban normatif bagi hakim untuk menerapkan hukum adat yang masih hidup dan berkembang dalam masyarakat dalam memriksa dan mengadili perkara perdata. Menurut ketentuan pasal tersebut nilai-nilai hukum adat merupakan sumber hukum, bagi hakim sumber hukum ini merupakan elemen yang penting dalam menyusun pertimbangan hakim sebuah putusan.

Hukum acara merupakan hukum yang imperative (dwingen) dan bukan hukum pelengkap (aanvullen). Keadilan yang ingin dicapai dalam hukum acara adalah keadilan yang sifatnya procedural, artinya bahwa keadilan tercapai jika prosedur pemeriksaan perkara sesuai perundang-undangan. Konsekuensinya Hukum Acara Perdata tidak dapat disimpangi, kecuali diperkenankan oleh undang-undang. Dalam praktek peradilan perdata hakim sering menemui kesulitan saat harus menerapkan hukum adat yang berdasarkan tahapan penyelesaian perkara perdata di pengadilan. Salah satu cara agar hakim mengetahui bahwa suatu sengketa harus diselesaikan berdasarkan norma dan 
asas-asas hukum adat adalah melalui tahap Tanya-jawab antara pihak penggugat dan tergugat yang menyatakan dalildalil.(Sulastriyono, 2012)

Dalil-dalil yang disampaikan dalam persidangan pada proses Tanya-jawab dan pembuktian tertulis dan saksi pada putusan ini menurut Hakim Ketua dan Hakim Anggota I tidak mengandung persoalan-persoalan hukum adat akan tetapi lebih pada persoalan ingkar janji seperti yang diatur dalam Pasal 1338 ayat (1) KUHPerdata dan diputuskan menurut ketentuan Pasal tersebut.

Pandangan hakim anggota II yang memandang bahwa dalam dalam suatu proses jual beli harus dipisahkan antara perjanjian pokok dan perjanjian tambahan. Perjanjian pokonya adalah jual beli, akan tetapi harga kesepakatan jual beli antara penggugat dan tergugat dipotong dari hubungan hutang piutang yang terjadi antara penggugat dengan tergugat I dan II yang tidak sepatutnya dilibatkan. Tatkala terjadi silang selisih antara penerapan hukum adat dan hukum negara, dalam arti keduanya memiliki kesempatan yang sama untuk terpilih sebagai dasar penyelesaian sengketa, maka hakim dapat melakukan forum shopping, yakni mencari sistem hukum mana yang paling sesuai, untuk penyelesaian klaim-klaim para pihak tersebut.
Para hakim mutlak perlu memiliki pengetahuan mendalam tentang hukum adat setempat.(Shidarta, 2010)

\section{KESIMPULAN}

Hukum positif betapapun lengkapnya tetap saja terbatas, ketika terjadi perbedaan penerapan antara hukum positif dan hukum adat, keduanya hendaklah memiliki kesempatan yang sama untuk dipilih sebagai dasar penyelesaian sengketa. Hakim selaku mahkotanya melalui putusannya mutlak perlu memiliki pengetahuan mengenai hukum adat yang berlaku di masyarakat, agar hukum tidak hanya berjalan sebagai positivistic/legalistic yang tertulis saja akan tetapi juga mengadopsi nilainilai adat yang berlaku dan tidak menempatkan hakim hanya sebagai corongnya undang-undang saja.

\section{DAFTAR PUSTAKA}

Amir, M., B. 2019. "Perlindungan Hukum Jual Beli Hak Atas Tanah Secara Lisan (Studi Putusan Nomor: 114/PDT/2015/PT.MDN)".Premise Law Jurnal, Vol. 13, 1-19.

Fence, M Wantu. 2013. "Kendala Hakim dalam Menciptakan Kepastian Hukum, Keadilan, dan Kemanfaatan di Peradilan perdata". Jurnal Mimbar Hukum, Vol. 25 No. 2, 205-218. 
Gayus, Lumbuun. 2004. Menerobos Goa Hantu Peradilan Indonesia. Jakarta: Businees Information Services.

Hadikusuma, Hilman. 1992. Pengantar Ilmu Hukum Adat Indonesia. Bandung: Mandar Maju.

Juju, Ahmad Jayus. 2019. "Eksistensi Pewarisan Hukum Adat Batak". Jurnal Yudisial, Vol. 12. No. 2, 235-253.

Putro, W. D. 2009. Perselisihan Hukum Modern Dan Hukum Adat Dalam Kasus Pencurian Sisa Panen Randu, 02, 113-129.

Shidarta. 2010. "Peragaaan Pola Penalaran Hukum Dalam Kajian Putusan Kasus Tanah Adat". Jurnal Yudisial, Vol. III. No. 03, 207-219.

Soekanto, S. 1984. Pengantar Penelitian Hukum. Penerbit Universitas Indonesia.

Sulastriyono, S. D. F. A. 2012. "Penerapan Norma dan Asas-Asas Hukum Adat dalam Praktik Peradilan Perdata". Mimbar Hukum, Vol. 24. No. 1, 1-186.

Suriyaman, M., P. 2014. Hukum Adat Dahulu, KIni dan Akan Datang (Edisi Pert). Jakarta: PRENADA MEDIA GROUP.

Suwito, S. 2015. Putusan Hakim yang Progresif dalam Perkara Perdata (Telaah "Kasus Pohon Mangga"). Hasanuddin Law Review, 1(1), 101. https://doi.org/10.20956/halrev.v 1n 1.43

Syamsudin, M. 2014. "Keadilan Prosedural dan Substantif Dalam Putusan Sengketa Tanah Magersari". Jurnal Yudisial, Vol. 7. No. 1, 18-33.

Tolib, Setiady. 2008. Intisari Hukum Adat Indonesia (Dalam Kajian Kepustakaan). Bandung: Alfabeta. 